Military Technical College Kobry Elkobbah, Cairo, Egypt.

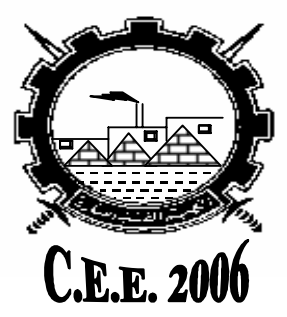

$3^{\text {rd }}$ International Conference

On

Chemical \& Environmental

Engineering

\title{
LIGHT WAX DISTILLATE TREATMENT VIA SOLVENT EXTRACTION AND HYDROFINISHING
}

\author{
Mohamed M. S. ", Hanafy S. A. * and \\ Abou Taleb .W. A.
}

\section{ABSTRACT}

The treatment of the light wax distillate using conventional lube manufacturing processes as solvent extraction, solvent dewaxing, and hydrofinishing has been investigated. Laboratory batch extraction of what from the light wax distillate was carried out using $\mathrm{N}$ methylpyrrolidone (NMP) containing $3 \mathrm{wt} \%$ water and the solvent/ oil ratio used was $3: 1$ at an extraction temperature of $50^{\circ} \mathrm{C}$.

The raffinate is then dewaxed using the solvent methyl ethylketone (MEK) together with toluene (60/40) at a solvent / oil ratio of $3 / 1$ and at a dewaxing temperature of $25^{\circ} \mathrm{C}$. The hydrofinishing was carried out using a commercial Nickel-Tungsten catalyst in a high pressure autoclave. The hydrofining product shows important considering properties as the viscosity variation $(\mathrm{V} 1=117)$, low temperature properties , (pour point $=-33 \mathrm{C}^{\circ}$ ), volatility (flash point $=186^{\circ} \mathrm{C}$ ) and the oxidation stability ( $\mathrm{t}=32 \mathrm{~min}$.) this higher quality product be used in blending thus preparing a appropriate compounded oil.

\section{KEY WORDS}

Solvent extraction, Solvent dewaxing and hydrofinishing 


\section{INTRODUCTION}

Base oils blended with additives to produce lubricants are complex mixtures of liquid hydrocarbons obtained as distillates or residues through the vacuum distillation of selected paraffinic or naphthenic crudes. Base oils are generally mixed with small amounts of performance enhancing additives to produce automotive and industrial lubricants. In terms of volume, base oil is the most important component of lubricant as it accounts for more than $95 \%$ of lubricants formulation. Moreover, some types of lubricants contain only $1 \%$ additives. Although there is an overall surplus of base oil supply on a worldwide basis, there are regions where a shortage of base oils exists [1].

Base oils differ widely in composition and in their physical and chemical properties according to the nature of the crude oil and the various applied processing steps in their manufacture. The difference in base oil composition has an impact on the enduse performance of the finished lubricant even if the base oils have similar physical properties [2] [3] [4]. Base oil contains thousands of different hydrocarbon molecules that are defined as paraffin's, naphthenes aromatics and hydroaromatics:

Conventional lube refining processes aim at the separation of undesirable components from vacuum distillates and deasphalted oil with hydrofinishing as the final step to improve the color and remove surface active substances which can negatively affect the air release value or demulsifying properties of a lubricating oil [5, 6 and 7]. In order to improve economics of the existing plants, conventional process technology is being continuously updated through innovations. This includes integration of hydrofining with solvent extraction processes in both up and down stream configuration.

The processing scheme referred to as the "Conventional Refining Route" was introduced some sixty years ago but is still used by the majority of the lube oil producers where the complex consists of four major process units $[8,9]$.

The vacuum oil distillation unit produces the lube distillates. The heaviest cut obtained is Solvent Neutral oil SNI200 (corresponding to a viscosity of about 18-20 cSt at $100^{\circ} \mathrm{C}$ ) which covers most of the high viscosity requirements should there be a need for special heavy oils: a brightstock has to be produced by deasphalting the vacuum residue. Otherwise, the vacuum residue may be used as a heavy fuel oil or as a feedstock for further bottom-of-the-barrel "processing.

In the solvent Refining unit, the viscosity index is improved by extraction of the aromatic compounds. The extract byproducts are highly aromatic, low pour point oils. These oils can be used as and extruder oils in the rubber industry, as Feedstocks for FCC units or even as a heavy fuel oil component. [10] . In the dewaxing unit, the pour point is improved by removing the paraffins. Dewaxing is carried out by chilling the oil in the presence of a solvent. The paraffin wax obtained as a byproduct can be deoiled and fractionated in an integrated deoiling plant. The deoiled wax can subsequently be refined for the various applications up to food grade quality.

The Hydrofinishing step is typically a mild hydrogenation process which involves little change in the molecular structure of the hydrocarbon components. [11-16] It is a finishing process used to improve base oil color, color stability and oxidation stability. 
As the flash point of the base grade oils is to be adjusted to meet specifications, a small amount (about 1\%) of slope oil is obtained as a byproduct.

\section{EXPERIMENTAL}

The feedstock used in this study is vacuum light wax distillate fractionated from a blend of Western Desert crude oils.

The physico-chemical properties of the light wax distillate are given in Table 1.

\section{Extraction temperature}

The extraction temperature for the solvent N-methylpyrrolidone (NMP) used in this treatment was determined according to the critical solution temperature (C.S.T.) of the solvent and feedstock. According to previous work [18] the selective experimental conditions are used as follows (solvent to feed ratio 3:1), and a temperature of $50 \mathrm{C}^{\circ}$.

\section{Extraction procedure}

The solvent extraction of the feedstock is carried out in a jacketed mixer settler apparatus. The extraction temperature was maintained constant using ultra thermostat. The time required for complete mass transfer and separation was fixed to be 45 minutes [6].

The two phases, raffinate and extract, were separated (due to the difference in their densities). The solvent was removed from the raffinate phase by washing with hot distilled water, six washings were carried out in each experiment for the removal of the solvent and then dried over anhydrous $\mathrm{CaCl}_{2}$ to removed the traces of water from the raffinate. The solvent was removed from the extract phase by distillation under reduced pressure. The physico-chemical characteristics of the raffinate were determined.

\section{Solvent dewaxing}

The raffinate obtained after the NMP $+3 \%$ water treatment was taken as the feedstock for a dewaxing process. The dewaxing process was carried out using solvent mixture composed of $60 \mathrm{wt} \%$ methyl ethyl ketone (MEK) and 40wt $\%$ toluene as a dewaxing solvent at a temperature of $-25 C^{\circ}$ and solvent to oil ratio of $3: 1[17]$.

\section{Hydrofinishing}

A commercial catalyst T-2593 used in this study has been kindly provided by a sudchemie AG catalyst supplier. The main characteristics and chemical composition of the catalyst are given in Table 2 .

\section{Hydrofinishing procedure}

The catalyst was presulphided before starting the reaction runs by treatment with naphtha previously doped with $20 \%$ dimethyl disulfide $\left(30 \mathrm{~cm}^{3} \mathrm{~m}^{-1}\right)$ which was passed through the catalyst at an atmospheric pressure and $400 \mathrm{C}^{\circ}$ for 6 hours. The hydrofinishing experiments were performed, in a high pressure batch autoclave (Parr model 4572) heated by a digital controller, the experimental conditions were selected according to pervious work [18], (temperature of $375 \mathrm{C}^{\circ}$ and a initial hydrogen pressure of $7 \mathrm{Mpa}$ was applied, catalyst to feed ratio was 1/10. While, the catalyst reaction time was 4 hours). 


\section{RESULTS AND DISCUSSION}

The aim of this work is to prepare and light lube oils in the laboratory for industrial applications. This necessitates the treatment of the feedstock using conventional lube manufacturing processes as solvent extraction, solvent dewaxing and hydrofinishing.

In selecting a solvent suitable for commercial application, solubility parameter, masstransfer phase separation and recovery properties are important criteria for selecting the solvent, as well as the process in which it is used. N-methyl 2 pyrrolidone (NMP) was preferably selected as a solvent not only due to its low cost and availability, but also due to its capability of extraction of both paraffininc and naphthanic stocks and its being superior to other solvents in terms of its stability. The extraction temperature for solvent and feedstock was determined according to the C.S.T. of the solvent and the feedstock at a fixed solvent/ feed ratio $3: 1$. The solvent free raffinate obtained from extraction of the light wax distillate using NMP at $50 \mathrm{C}^{\circ}$ and a solvent/ oil ratio of $3: 1$ was taken as the feed stock for dewaxing process Table 3.

Dewaxing of the raffinate was carried out using mixtures of methyl ethyl ketone and toluene (60:40 by volume) at a solvent to feed ratio of $3: 1$ and a dewaxing temperature $-25^{\circ} \mathrm{C}$. The yield of the dewaxed oil calculated on raffinate bases used $74 \%$ by wt. The effect of dewaxed process upon the nature of the raffinate is reflected by the decrease in viscosity index, pour point and flash point while density, viscosity, sulphur and aromatic content increased (Table 4). This is due to the decrease of the saturated constituents and consequently the corresponding increase in the percentage of aromatic components.

The viscosity index, sulfur content, specific gravity, pour point and flash point of the base oil stocks determine the value of the base stock to down stream companies that blend and manufacture lubricants.

Most of the bulk properties of base oils depend on the hydrocarbon type distribution, and on the relative amount of each type. Results obtained, as given in figure $(1,2)$ show the effect of solvent refining on component analysis of the raffinate indicating that the conditions applied for solvent extraction enhances selectivity towards increasing. monoaromatics and diaromatics from 19.44 to $20.1 \%$. The aromatic components decrease from 37.84 to $24.85 \%$ while the saturated component increases from 62.16 to $75.15 \%$.

The effect of hydrotreatment on the dewaxed oil was shown in figure 2 which indicates that the monoaromatics increased from 4.95 to $22.26 \%$ accompanied by the decrease in diaromatics. The increase of monoaromatics may be due to partial saturation of the diaromatics or due to the decomposition of the heterocyclic compounds to monoaromatics compounds. Table (5) gives the characteristics of the product obtained after the hydrofining of dewaxed light vacuum distillate. Good quality and better performance expected as shown by the viscosity index $(\mathrm{V} 1=117)$, low temperature properties (pour point $=-33 \mathrm{C}^{\circ}$ ), volatility $\left(\right.$ flash point $=186 \mathrm{C}^{\circ}$ ) and oxidation performance (oxidation stability=32 min.). It is well known that the lower viscosity base stocks can be used as blending stocks for higher viscosity base stocks in compounded oil formulation to meet the tight volatility specification and to obtain the right viscosity grade. Therefore, the hydrofining light dewaxed oil (viscosity at 
$100 \mathrm{C}^{\circ}=2.7 \mathrm{cSt}$ ) may be used in blending for the preparation of appropriate compounded oils. The results given in table (6) indicate that the characteristics of the hydrofining light dewaxed oil product are within range of the oil recommended for lubrication of high speed spindle bearings in machine tools, as precision grinders requiring low viscosity oils (Mobile Velocite oil No6) as well as lubricant of nonadditive machine oil equipment.

\section{CONCLUSION}

- The product from hydrofining of the light dewaxed oil may be used in blending for the preparation of appropriate compounded oil

- According to the characteristics of the resultant oil, it can be recommended for lubrication of high speed spindle bearings in machines.

\section{REFERENCES}

[1] Pirro, D.M and Wessol, A.A. Lubrication Fundamentals, $2^{\text {nd }}$ edition Marcel Dekker, New York, p.306, (2001).

[2] Deane, B.C. Modern Petroleum Technology, John Wiley, New York, p.324, (2000).

[3] Terry, E.H.; Thomas, F.D.J; Dominick, N.M.; Mary, P.M; Tim, L.H. and Rick, C. OG J vol. 96, p.58, (1998).

[4] Giri, C.C. and Sharama, D.K. Fuel, vol.79, pp.577-585 (2000).

[5] John, J.M. Petroleum Processing Handbook, Marcel Dekker, New York, p. 643 (1992).

[6] Renee, I.A. Mamdouh S.M and Safaa, T.K. Egypt J. Petrol. Vol. 7 p.1 (1998).

[7] Qi, Y.; Li, H.; Qin, S. Pet. Sci. Technol. Vol.19 (3 \& 4), p.403 (2001).

[8] Marafi A.; Fukase S.; Al-Marri, M and Stanislaus,A. Energy \& Fuels,vol.17, p.661 (2003).

[9] Gerard, D. PTQ Autumn, p. 139 (2000).

[10] Gray, M.R. Upgrading petroleum Residues and Heavy Oils Marcel Dekker, New York, p. 147 (1994).

[11] Wang, Y.; Li, R. Pet Sci Technol. Vol.18 ( 7\&8), p.965 (2000).

[12] Babich, I.V.; Moulijn, J.A. Fuel vol. 82, pp.607-613 (2003).

[13] Hournae, R. OGJ. Vol. 86 (2), p.58 (1988).

[14] La Bracio, D.S. and Johnson, P.C., Symposium on processing characterization and application of lubricating Base oils, Part II American Chemical Society. (1994).

[15] Sastry, M.I.S. Mukherjee, S. and Sarpal A.S. Fuel, Volume 79, pp. 1833-1841 (2000).

[16] Maria Luisa A. Goncalves, Daniel A. Ribeire, R.F. Teixera and Marco Antonio G. Teixeira Fuel Volume 85, pp.1151-1155 (2006).

[17] EL- Shafey, M.A., Amal, S.F. and Youssef, M.H. Bull- NCR, Egypt, vol. 10, p.94 (1985).

[18] Wael A. Abou -Taleb : prepration of lubricating oils by selective refining processes for industrial application. M. Sc. Thesis , Al Azher University , 169 p, (2004) . 
Table (1): Physico-Chemical Characteristics of the Vacuum Light Wax Distillate Feedstock

\begin{tabular}{|c|c|c|}
\hline Characteristics & ASTM method & Results \\
\hline Refractive Index at $70 \mathrm{C}^{\circ}$ & ASTM D1218 & 1.4739 \\
\hline Kinematic viscosity at $40 \mathrm{C}^{\circ}, \mathrm{cSt}$ & ASTM D 445 & 11.4 \\
\hline Kinematic viscosity at $100 \mathrm{C}^{\circ}, \mathrm{cSt}$ & & 2.8 \\
\hline Viscosity Index & ASTM D2270 & 82 \\
\hline Density at $70 \mathrm{C}^{\circ} \mathrm{gm} / \mathrm{cm} 3$ & ASTM D1480 & 0.8662 \\
\hline Specific Gravity 15/15 Co & & 0.9047 \\
\hline Mean molecular weight & & 233 \\
\hline Flash point $\mathrm{C}^{\circ}$ & ASTM D 92 & 189 \\
\hline Pour point $\mathrm{C}^{\circ}$ & ASTM D 97 & 20 \\
\hline Viscsoity Gravity Constant & ASTM D 2501 & 0.8744 \\
\hline Component analysis (wt.\%) & \multicolumn{2}{|c|}{ Mair and Rossini (1958) } \\
\hline Total saturates & & 62.16 \\
\hline Mono aromatics & & 16.8 \\
\hline Di aromatics & & 19.44 \\
\hline Poly aromatics & & 0.47 \\
\hline Resin & & 1.13 \\
\hline Total aromatics & & 37.84 \\
\hline Sulfur content (wt\%) & ASTM D 1552 & 1.62 \\
\hline
\end{tabular}

Table (2): The main characteristics and chemical composition of the commercial catalyst T-2293.

\begin{tabular}{|l|c|}
\hline \multicolumn{1}{|c|}{ Characteristics } & Results \\
\hline Bulk density $(\mathrm{g} / \mathrm{ml})$ & 0.70 \\
\hline Total pore volume cc $/ \mathrm{g}$ & 0.61 \\
\hline BET surface area $\mathrm{m}^{2} / \mathrm{g}$ & 240 \\
\hline Average pore diameter $\mathrm{A}^{\circ}$ & 101.7 \\
\hline CDS-Extrusions & $1.6 \mathrm{~mm}$ \\
\hline Chemical composition wt. $\%$ & \\
\hline $\mathrm{Ni} \mathrm{O}^{\mathrm{O}}$ & $5.0 \mathrm{wt} \%$ \\
\hline $\mathrm{WO}_{3}$ & $22.0 \% \mathrm{wt}$ \\
\hline $\mathrm{Al}_{2} \mathrm{O}_{3}$ & balance \\
\hline
\end{tabular}


Table (3): Physico-Chemical Characteristics of the Treated Light Wax Distillate Feedstock (Viscosity at $100^{\circ} \mathrm{C}=2.8 \mathrm{cSt}$ )

\section{Using N-methyl-2-Pyrrolidone + 3\% distilled water}

Extraction temperature $=50^{\circ} \mathrm{C}$ Solvent $:$ feed $=3: 1$

\begin{tabular}{|c|c|c|}
\hline Characteristics & ASTM method & Results \\
\hline C.S.T. Co & & 80 \\
\hline Yield (wt.\%) & & 71.8 \\
\hline Refractive Index at $70 \mathrm{C}^{\circ}$ & ASTM D1218 & 1.4562 \\
\hline Kinematic viscosity at $40 \mathrm{C}^{\circ}, \mathrm{cSt}$ & ASTM D 445 & 9.9 \\
\hline Kinematic viscosity at $100 \mathrm{C}^{\circ}, \mathrm{cSt}$ & & 2.7 \\
\hline Viscosity Index & ASTM D2270 & 112 \\
\hline Density at $70 \mathrm{C}^{\circ} \mathrm{gm} / \mathrm{cm}^{3}$ & ASTM D1480 & 0.8097 \\
\hline Specific Gravity $15 / 15$ C $^{\circ}$ & & 0.8174 \\
\hline Mean molecular weight & & 273 \\
\hline Flash point $\mathrm{C}^{\circ}$ & ASTM D 92 & 186 \\
\hline Pour point $\mathrm{C}^{\circ}$ & ASTM D 97 & 13 \\
\hline Viscosity Gravity Constant & ASTM D 2501 & 0.8174 \\
\hline Component analysis (wt.\%) & \multicolumn{2}{|c|}{ Mair and Rossini (1958) } \\
\hline Total saturates & & 75.15 \\
\hline Mono aromatics & & 3.72 \\
\hline Di aromatics & & 20.10 \\
\hline Poly aromatics & & 0.0 \\
\hline Resins & & 1.03 \\
\hline Total aromatics & & 24.85 \\
\hline Sulfur content (wt\%) & ASTM D 1552 & 1.13 \\
\hline Refining Effectiveness Number & & 0.9797 \\
\hline
\end{tabular}


Table (4): Physico-Chemical characteristics of the dewaxed oil for the vacuum light wax distillate raffinate

Solvent composition MEK/Toluene (60/40) solvent $/$ feed ratio = 3:1 dewaxing temperature $=-25^{\circ} \mathrm{C}$

\begin{tabular}{|c|c|c|}
\hline Characteristics & ASTM method & Results \\
\hline Oil yield on raffinate (wt.\%) & & 74 \\
\hline Refractive Index at $70 \mathrm{C}^{\circ}$ & ASTM D1218 & 1.4598 \\
\hline Kinematic viscosity at $40 \mathrm{C}^{\circ}, \mathrm{cSt}$ & ASTM D 445 & 12 \\
\hline Kinematic viscosity at $100 \mathrm{C}^{\circ}, \mathrm{cSt}$ & & 2.9 \\
\hline Viscosity Index & ASTM D2270 & 84 \\
\hline Density at $70^{\circ} \mathrm{C} \mathrm{gm} / \mathrm{cm}^{3}$ & ASTM D1480 & 0.8363 \\
\hline Specific Gravity $15 / 15 C^{\circ}$ & & 0.8769 \\
\hline Mean molecular weight & & 214 \\
\hline Flash point $\mathrm{C}^{\circ}$ & ASTM D 92 & 185 \\
\hline Pour point $\mathrm{C}^{\circ}$ & ASTM D 97 & -36 \\
\hline Viscosity Gravity Constant & ASTM D 2501 & 0.8408 \\
\hline Component analysis (wt.\%) & \multicolumn{2}{|c|}{ Mair and Rossini (1958) } \\
\hline Total saturates & & 68.46 \\
\hline Mono aromatics & & 4.95 \\
\hline Di aromatics & & 22.89 \\
\hline Poly aromatics & & 0.0 \\
\hline Resins & & 3.7 \\
\hline Total aromatics & & 31.54 \\
\hline Sulfur content (wt\%) & ASTM D 1552 & 1.44 \\
\hline
\end{tabular}


Table (5): Effect of hydrofining on the dewaxed oil of light Vacuum distillate (Viscosity at $100^{\circ} \mathrm{C}=2.9 \mathrm{cSt}$ )

$\left(\right.$ Reaction Temperature $=375^{\circ} \mathrm{C}$, Intial Pressure $=7.0 \mathrm{Mpa}$, Catalyst $/$ oil Ratio $\left.=10 \%\right)$

\begin{tabular}{|c|c|c|}
\hline Characteristics & Feed & Result \\
\hline \multicolumn{3}{|l|}{ Products, wt $\%$} \\
\hline Hydrocarbon gases + coke & & $7.0 \%$ \\
\hline Light liquid $\left(<380^{\circ} \mathrm{C}\right)$ yield & & 3.0 \\
\hline Heavy liquid $\left(>380 C^{\circ}\right)$ yield & & $90.0 \%$ \\
\hline Total conversion wt $\%$ & & 10 \\
\hline Hydrodesulphurization (HDS) wt\% & & 88.89 \\
\hline Aromatic hydrogenation $\%$ & & 18.83 \\
\hline \multicolumn{3}{|l|}{$\begin{array}{l}\text { Characteristics of heavy oil product } \\
\left(>380 \mathrm{C}^{\circ}\right)\end{array}$} \\
\hline Refractive Index at $70 \mathrm{C}^{\circ}$ & 1.4598 & 1.4549 \\
\hline Density at $70 \mathrm{C}^{\circ} \mathrm{gm} / \mathrm{cm}^{3}$ & 0.8363 & 0.8246 \\
\hline $\mathrm{API}$ & 30.01 & 30.3 \\
\hline Kinematic viscosity at $40 \mathrm{C}^{\circ}$, cst & 12 & 10.9 \\
\hline Kinematic viscosity at $100 \mathrm{C}^{\circ}, \mathrm{cSt}$ & 2.9 & 2.7 \\
\hline Viscosity Index & 84 & 117 \\
\hline Mean molecular weight & 273 & 214 \\
\hline Pour point $\mathrm{C}^{\circ}$ & -36 & -33 \\
\hline Flash point $\mathrm{C}^{\circ}$ & 185 & 186 \\
\hline Total Sulfur content, wt\% & 1.44 & 0.16 \\
\hline Colour & 3.0 & 0.5 \\
\hline Total nitrogen content, wt $\%$ & 0.72 & 0.28 \\
\hline Specific Gravity $15 / 15$ C $^{\circ}$ & 0.8769 & 0.8752 \\
\hline Viscosity Gravity Constant & 0.8408 & 0.8411 \\
\hline Component analysis (wt\%) & & \\
\hline Total saturates & 68.46 & 74.4 \\
\hline Total aromatics & 31.54 & 25.6 \\
\hline Mono aromatics & 4.95 & 22.26 \\
\hline Di aromatics & 22.89 & 1.56 \\
\hline Poly aromatics & 0.0 & 0.0 \\
\hline Resins & 3.7 & 1.78 \\
\hline Oxidation stability, minute (IP 229) & & 32 \\
\hline
\end{tabular}


Table (6): Characteristics of the hydrofined oil product (Viscosity at $100^{\circ} \mathrm{C}=2.7 \mathrm{cSt}$ ) with some produced lube oils from international companies

\begin{tabular}{|l|c|c|c|}
\hline \multicolumn{1}{|c|}{ Characteristics } & Hyd. Oil & $\begin{array}{c}\text { Mobil * }^{*} \\
\text { Velocite oil }\end{array}$ & $\begin{array}{c}\text { Shell }^{* *} \text { Vitrea } \\
\text { oil }\end{array}$ \\
\hline ISO grade & & 10 & 13 \\
\hline API Gravity & 30.01 & & 35.2 \\
\hline Kinematic viscosity at 40 C', cSt & 10.9 & 9.4 & 12.1 \\
\hline Kinematic viscosity at $100 \mathrm{C}^{\circ}, \mathrm{cSt}$ & 2.7 & 2.5 & 3.1 \\
\hline Viscosity Index & 117 & 90 & 95 \\
\hline Pour point Co & -33 & -10 & -15 \\
\hline Flash point C & 186 & 160 & 205 \\
\hline Carbon residue Ramsbottom, wt\% & -- & --- & 0.05 \\
\hline Oxidation stability, minute (IP 229) & 32 & --- & -- \\
\hline
\end{tabular}

* High speed spindle bearing and hydrolic oil from Mobil Company

** Paper machine oil 